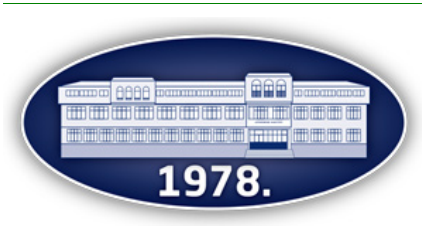

Publisher: Faculty of Agronomy Čačak

\title{
How long can primed soybean (Glycine max L.) seeds be stored in natron paper bags?
}

\author{
Zlatica Mamlić1*, Ivana Maksimović2 , Jovan Crnobarac², Vuk Đorđević1, \\ Marina Delić Putnik ${ }^{2}$, Vojin Đukić1 ${ }^{1}$ Ana Uhlarik ${ }^{1}$ \\ ${ }_{1}$ Institute of Field and Vegetable Crops, Maksima Gorkog 30, 21000 Novi Sad, Serbia \\ 2 Faculty of Agriculture, University of Novi Sad, Dositeja Obradovica 8, 21000 Novi Sad, Serbia. \\ *Corresponding author: zlatica.miladinov@ifvcns.ns.ac.rs
}

Received 12 May 2021; Accepted 21 October 2021

\begin{abstract}
A B S T R A C T
Priming of legume seeds before sowing was performed by Roman farmers in order to increase the germination rate and synchronize germination, as reported by the Roman naturalist Gaius Plinius Secundus. Several centuries later, this technique is still used for a wide range of species. However, in order for this measure to be used successfully in production, it is necessary to find a solution for the successful storage of primed seeds. The storage potential of primed soybean seeds was determined by a temperature of $25^{\circ} \mathrm{C}$ during the period of 90 days. Soybean seeds were primed with $\mathrm{KNO}_{3}(1 \%), \mathrm{AsA}(100 \mathrm{mg} \mathrm{L}-1)$ and $\mathrm{KCl}^{-1}(1 \%)$ solutions, and then stored in natron paper bags, and their quality was tested every 15 days. The results showed that a reduction in the quality of primed seeds was considerably faster than in non-primed seeds. Primed soybean seeds were successfully stored at a temperature of $25^{\circ} \mathrm{C}$ for 60 days after priming, and then a significant reduction in their quality occurred. One of the causes of seed quality reduction was an increase in MDA content, especially after 75 and 90 days of storage. Also, free proline concentration was reduced while the content of vitamin $\mathrm{C}$ increased after 15 days primarily in seeds primed in AsA and $\mathrm{KCl}$ solutions, and decreased after 45 days.
\end{abstract}

Keywords: germination, Glycine max (L.), priming, storage

\section{И 3 В О д}

Римски природњак Гај Плиније Секунд истиче да су још Римљани потапали семе манунарки у циљу побољшања клијавости и уједначеног ницања биљака. Неколико векова касније, потапање се и даље користи код великог броја биљних врста. Међутим, да би се ова предсетвена мера успешно користила у производњи, неопходно је да се пронађе решење за успешно чување потапаног семена. Могућност чувања потапаног па осушеног семена утврђена је његовим складиштењем на температури од $25^{\circ} \mathrm{C}$ у трајању од 90 дана. Семе соје је потапано у растворе: калијум-нитрат - КNO 3 (1\%), аскорбинска киселина - AsA (100 mg l-1) и калијум-хлорид - $\mathrm{KCl}(1 \%)$, чувано је у натрон (папирним) врећама и сваких 15 дана испитиван је његов квалитет. Резултати су показали да се квалитет потапаног семена брже смањује него непотапаног. Потапано семе соје може успешно да се чува на температури од $25^{\circ} \mathrm{C}$ током 60 дана, а потом долази до значајног смањења његовог квалитета. Један од узрока смањења квалитета семена је повећање садржаја МДА, посебно након 75 и 90 дана складиштења. Такође, смањена је концентрација слободног пролина, док је садржај витамина С повећан након 15 дана, пре свега у семену потапаном у растворе AsA и KCl. Након 45 дана дошло је до смањења садржаја витамина С.

\section{Кључне речи: клијавост, Glycine max (L.), потапање, складиштење}

\section{Introduction}

Every year, seeds are sown on more than $2 / 3$ of the total world arable land, accounting for about $90 \%$ of human needs in the food and agro-processing industry (Mirić and Brkić, 2002). Achieving high yields requires the use of quality seed (Miloševic et al., 1996). Germination and germination energy are the most important indicators of seed quality (Poštić et al., 2010). Therefore, various methods are used to increase seed germination, such as priming (Miladinov et al., 2018) and biostimulants (Cvijanović et al., 2020). However, storage of primed seeds is a major problem for the successful application of primed seeds. Many studies have shown that the quality of primed seeds decreases faster after a certain period than the quality of non-primed seeds (Dolatabadian et al., 2010), due to various factors. The length of storage of treated seeds largely depends on seed priming duration (Nirmala et al., 2014). Saracco et al. (1995) found that, in seeds exposed to priming longer than necessary, DNA replication can begin. Seeds in which replication began, i.e., seeds in which a new cell cycle began, and was then interrupted during seed drying, after priming, are significantly more sensitive and lose germination faster than seeds that were not exposed to priming. It is necessary to find a solution considering the exact time of priming, the concentration of the solution, and 
storage conditions for primed seeds. When all these conditions are met, seed priming, as a pre-sowing technique, can lead to improvements in agricultural production, especially in areas that do not have enough rainfall and where there is a high salt concentration in the soil solution (Sivasubramaniam et al., 2011; Giri et al., 2021).

Therefore, the aim of the study was to examine how long primed seeds can be stored without reducing their quality.

\section{Materials and methods}

Seeds of two soybean varieties, Victoria and NS Zita, selected at the Institute of Field and Vegetable Crops in Novi Sad, were used for the analysis. The Victoria variety belongs to maturity group 1 , and the NS Zita variety belongs to maturity group 2 . Seed was produced at the experimental field of the Institute of Field and Vegetable Crops. Both cultivars had the same initial value of seed germination (88\%), and a moisture content of 10 to $11 \%$.

Before priming, the seeds were surface sterilized with $3 \%$ sodium hypochlorite $(\mathrm{NaOCl})$ solution for two minutes and washed with distilled water. Then, seeds were primed in solutions: potassium nitrate - KNO3 (1\%), ascorbic acid - AsA (100 $\mathrm{mg} \mathrm{l}^{-1}$ ) and potassium chloride - $\mathrm{KCl}(1 \%)$. The ratio of seed volume to solution volume was 1:5 (v / v). After $6 \mathrm{~h}$ of priming (Miladinov et al., 2015; Miladinov et al., 2020), seeds were washed with distilled water and dried at a temperature of $25{ }^{\circ} \mathrm{C}$ to a humidity of $10-11 \%$. The storage potential of dried primed seeds was determined by their storage at a temperature of $25^{\circ} \mathrm{C}$ for 90 days. The seeds were stored in natron paper bags and their quality was examined every 15 days.
The working sample consisted of $4 \times 50$ seeds. In Petri dishes with a diameter of $9 \mathrm{~cm}$, the seeds were evenly placed on sterile filter paper. All Petri dishes were closed with paraffin tape to prevent moisture loss and avoid contamination. Petri dishes with seeds were placed in a germination chamber at a temperature of 25 ${ }^{\circ} \mathrm{C}$ for 8 days. After five days, germination energy was determined, and after eight days, germination was assessed based on the number of typical seedlings (Rules ISTA, 1996).

After treatment, 10 average seedlings (from each replication) were taken for biochemical analyses. The intensity of lipid peroxidation was determined by the method of Placer et al. (1966). The concentration of free proline was measured by the Bates method (1973). The content of vitamin $\mathrm{C}$ in the aqueous extract was assessed by the method of Benderitter et al. (1998).

Data analysis was performed using the Statistica statistical software package (StatSoft, Inc., Tulsa, Oklahoma, USA). The obtained results were processed by the three-way analysis of variance. The individual testing of probability was conducted by Tukey's method at $P \leq 0.05$ and $P \leq 0.01$.

\section{Results and discussions}

All analyzed traits differed significantly with regard to length of seed storage, treatment, and seed priming solution, while no difference was found between varieties. A significant difference was also found in the interaction between storage period and treatment. There was no interaction between variety and treatment, i.e., in the case of the three-factorial interaction of varieties, storage period and treatment (Table 1).

Table 1.

A significant difference was found in the interaction between factors

\begin{tabular}{|c|c|c|c|c|c|}
\hline \multirow[t]{2}{*}{$\begin{array}{l}\text { Source of } \\
\text { variation }\end{array}$} & $\begin{array}{c}\text { Germination } \\
\text { energy }\end{array}$ & Germination & $\begin{array}{c}\text { Lipid } \\
\text { peroxidation }\end{array}$ & Free proline & Vitamin C \\
\hline & \multicolumn{2}{|c|}{ Soybean seeds } & \multicolumn{3}{|c|}{ Soybean seedlings } \\
\hline Variety (A) & 0.37 & 0.54 & 2.05 & 2.15 & 1.78 \\
\hline Seed storage (B) & $9.25^{* *}$ & $7.12^{* *}$ & $8.14^{* *}$ & $5.74^{* *}$ & $3.81^{*}$ \\
\hline Treatment (C) & $5.01^{* *}$ & $5.09^{* *}$ & $6.26^{*}$ & $6.01^{* *}$ & $3.07 *$ \\
\hline $\mathrm{A} \times \mathrm{B}$ & 0.76 & 0.9 & 2.47 & 2.17 & 0.51 \\
\hline $\mathrm{A} \times \mathrm{C}$ & 1.71 & 1.34 & 2.12 & 1.49 & 0.97 \\
\hline $\mathrm{B} \times \mathrm{C}$ & $7.28^{* *}$ & $8.07^{* *}$ & $7.33^{* *}$ & $6.18^{* *}$ & $3.01^{*}$ \\
\hline $\mathrm{A} \times \mathrm{B} \times \mathrm{C}$ & 0.97 & 1.04 & 1.91 & 1.17 & 1.01 \\
\hline
\end{tabular}

\subsection{Germination results}

The results of the research showed that soybean seeds, after priming, were successfully stored for up to 60 days at a temperature of $25^{\circ} \mathrm{C}$ in paper bags, following which there was a decrease in their quality. In the period from 60 to 75 days, the germination energy was reduced, compared to the control, by $60.33 \%$ on average, i.e., the absolute value dropped below $40 \%$. Germination was also reduced, but to a lesser extent in relation to the energy of seed germination. Germination was significantly reduced in the period from 75 to 90 days of storage, when the absolute value dropped below 30\% (Figures 1, 2). Ninety days after seed priming, the reduction in germination energy and germination of primed seeds in relation to non-primed seeds was $68.33 \%$ and $65 \%$, respectively. When it comes to examining the storage potential of primed seeds, there were contradictory results. Argerich and Bradford (1989) primed tomato seeds in a combination of a solution of $120 \mathrm{mM} \mathrm{K}_{2} \mathrm{HPO}_{4}$ $+150 \mathrm{mM} \mathrm{KNO}_{3}$. They reported that primed tomato seeds stored at $30^{\circ} \mathrm{C}$ had a lower percentage of germinated seeds after 6 months of storage compared to non-primed seeds. Drew et al. (1997), on the other hand, found that storage of primed onion and leek seeds for 12 months at $10^{\circ} \mathrm{C}$ did not have a significant effect on the total number of germinated seeds, but had a negative effect on germination energy. Owen and Pill (1994) observed that the maximum germination of asparagus and tomato seeds was preserved for as long as three months after storage at $4{ }^{\circ} \mathrm{C}$, which was not the case with primed seeds stored at $20^{\circ} \mathrm{C}$. Dolatabadian et 
al. (2010) pointed out that priming is a favorable measure to improve seed germination at the beginning of storage, and that after a certain time this seed loses germination much faster than non-primed seed, which is in line with our research results. Seeds primed in $\mathrm{KNO}_{3}$ solution had the best germination after 90 days of storage. Alboresi et al. (2005) pointed out that potassium has the ability to neutralize various organic anions and other compounds within the cell, thus helping to stabilize the $\mathrm{pH}$ between 7 and 8 , which is optimal for most enzymatic reactions. Also, the amount of nitrate increases, which stimulates seed germination.

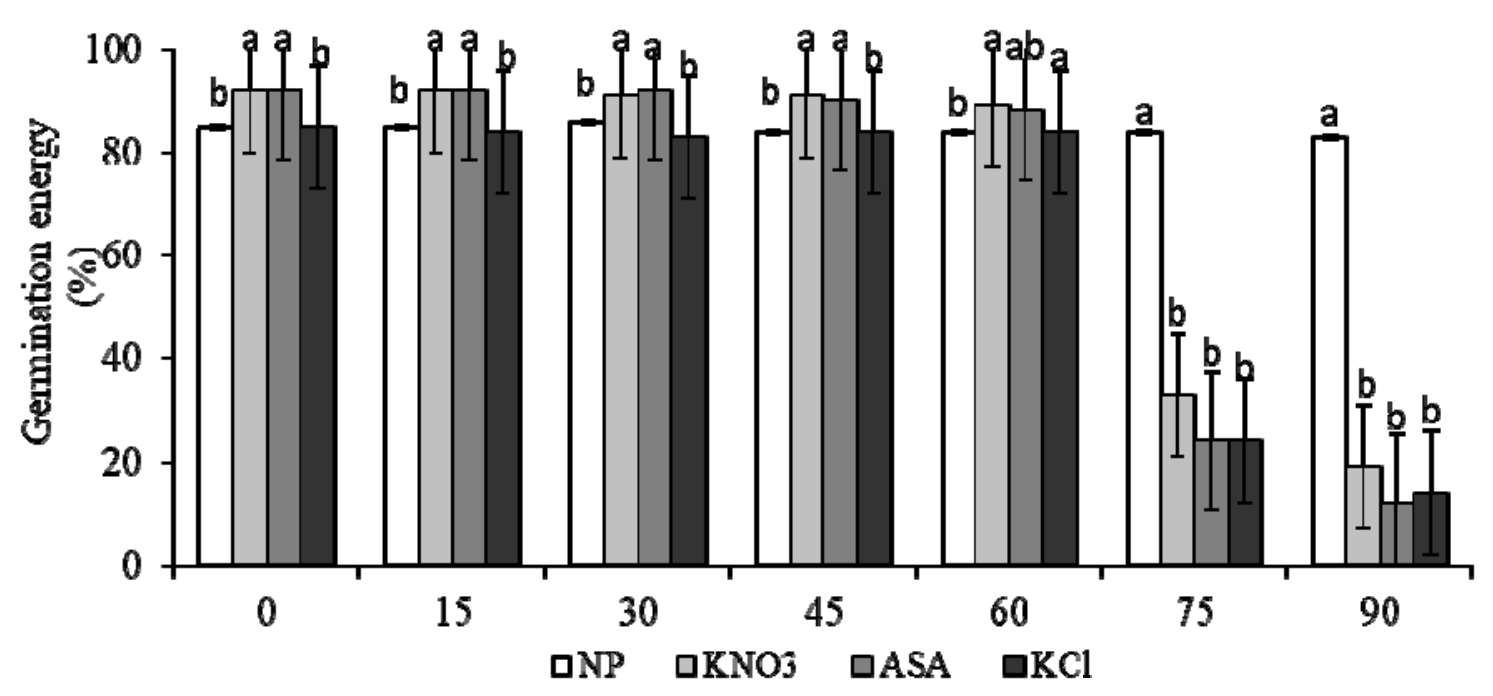

Figure 1. Effect of priming on germination energy (\%) during seed storage (Values marked by the same letter are not significantly different at $P=0.01$ level of probability -Tukey's Multiple Range Test)

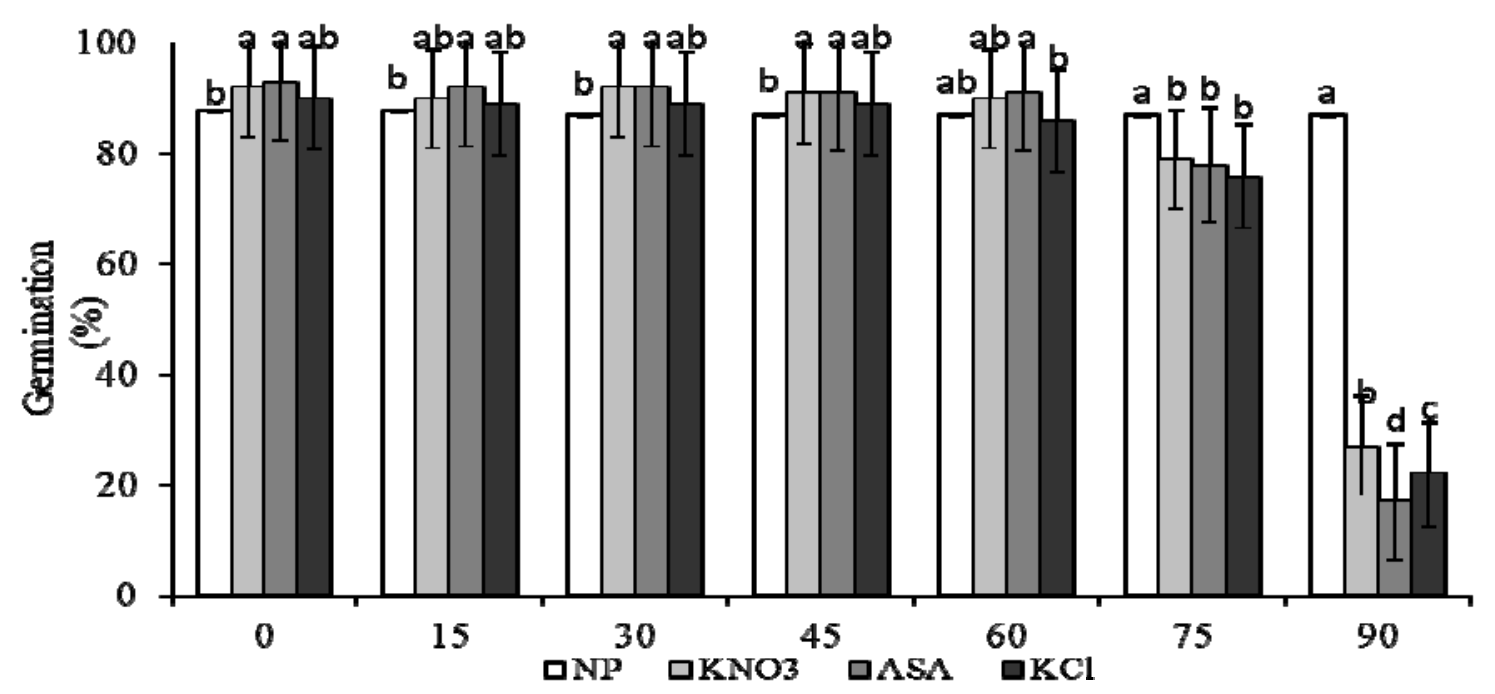

Figure 2. Effect of priming on germination (\%) during seed storage (Values marked by the same letter are not significantly different at $P=0.01$ level of probability - Tukey's Multiple Range Test)

\subsection{Biochemical parameters}

Storage of primed seeds under unfavorable conditions leads to disturbances in antioxidant processes (Chang and Sung, 1998) and damage to cellular structures, causing a disturbance in metabolic processes (Vijayakumar et al., 2019). Van Pijlen et al. (1996) emphasized that primed seeds stored under unfavorable conditions lose quality due to many biochemical processes that take place in them, which results in reduced DNA replication, i.e., the beginning of a new cell cycle. Seed priming activates antioxidants that reduce the negative effect of reactive oxygen species and decrease the intensity of lipid peroxidation, thus extending the life of seeds. In addition to reducing the intensity of lipid peroxidation, priming (Arun et al., 2017) also reduces the concentration of hexanal, a secondary product of lipid peroxidation, which adversely affects seed vitality. The results are partly in agreement with soybean research (Figure 3). In non-primed seeds, there was no significant change in MDA content in the period of up to 90 days of storage. 


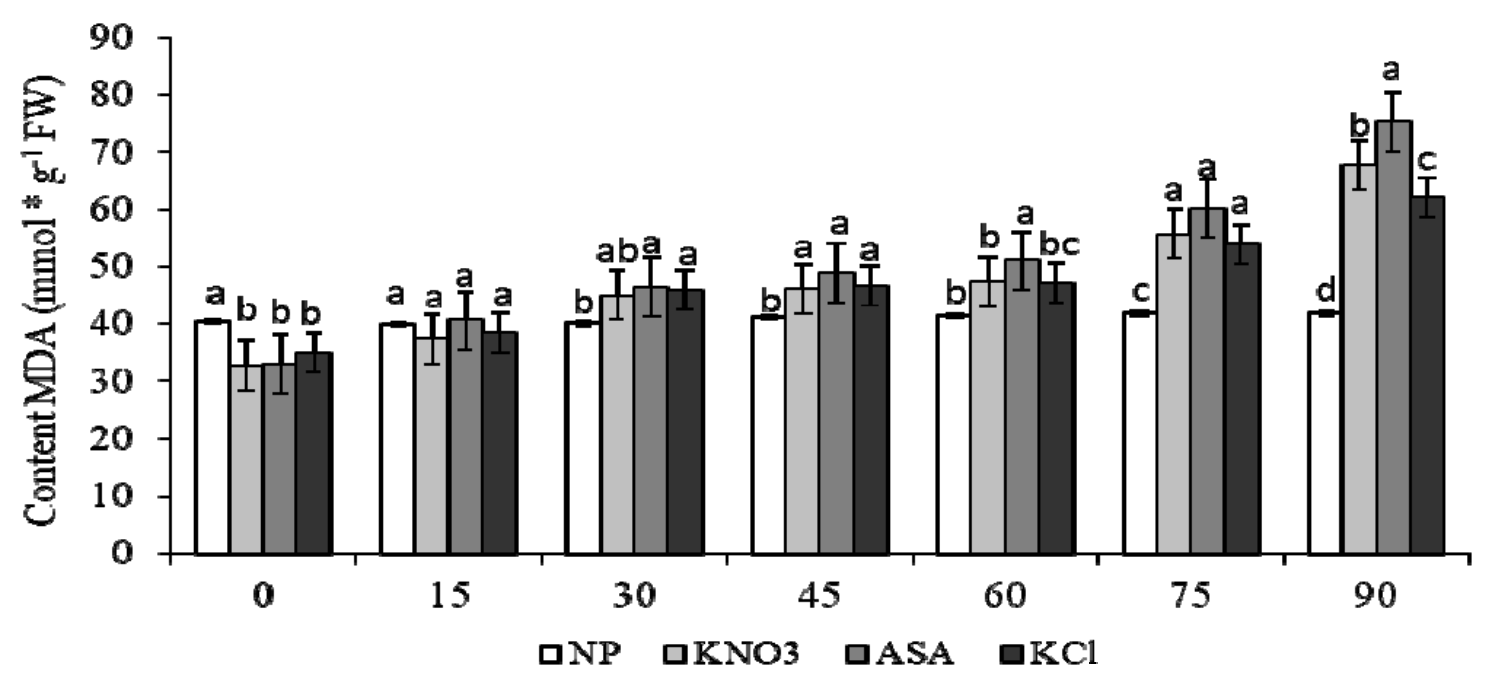

Figure 3. Effect of priming on MDA content (mmol/gFW) during storage (Values marked by the same letter are not significantly different at $P=0.01$ level of probability - Tukey's Multiple Range Test)

However, in primed seeds, the intensity of lipid peroxidation decreased immediately after priming, and began to increase after 15 days of storage. After 60 days, there was a significant increase in MDA content, and 90 days after priming, the intensity of lipid peroxidation increased, on average, by $38.41 \%$ compared to non-primed seeds. The results can be explained by the fact that the deterioration in the quality of seeds with a higher oil content, such as soybean seeds, is due to the increased intensity of lipid peroxidation and free fatty acids (Meena et al., 2017). Primed seeds are even more sensitive, because biochemical processes are initiated in them and, hence, the quality quickly decreases. The solutions with primed seeds had different effects on the intensity of lipid peroxidation. The concentration of MDA grew significantly faster in seeds primed in AsA; after 90 days, the intensity of lipid peroxidation increased by $44.37 \%$ compared to non-primed seeds. Seed priming also affected free proline content. The concentration of free proline began to decrease immediately after priming. Up to 75 days after seed priming, free proline concentration gradually decreased; 90 days after priming, free proline content decreased by $52.67 \%$ compared to non-primed seeds (Figure 4).

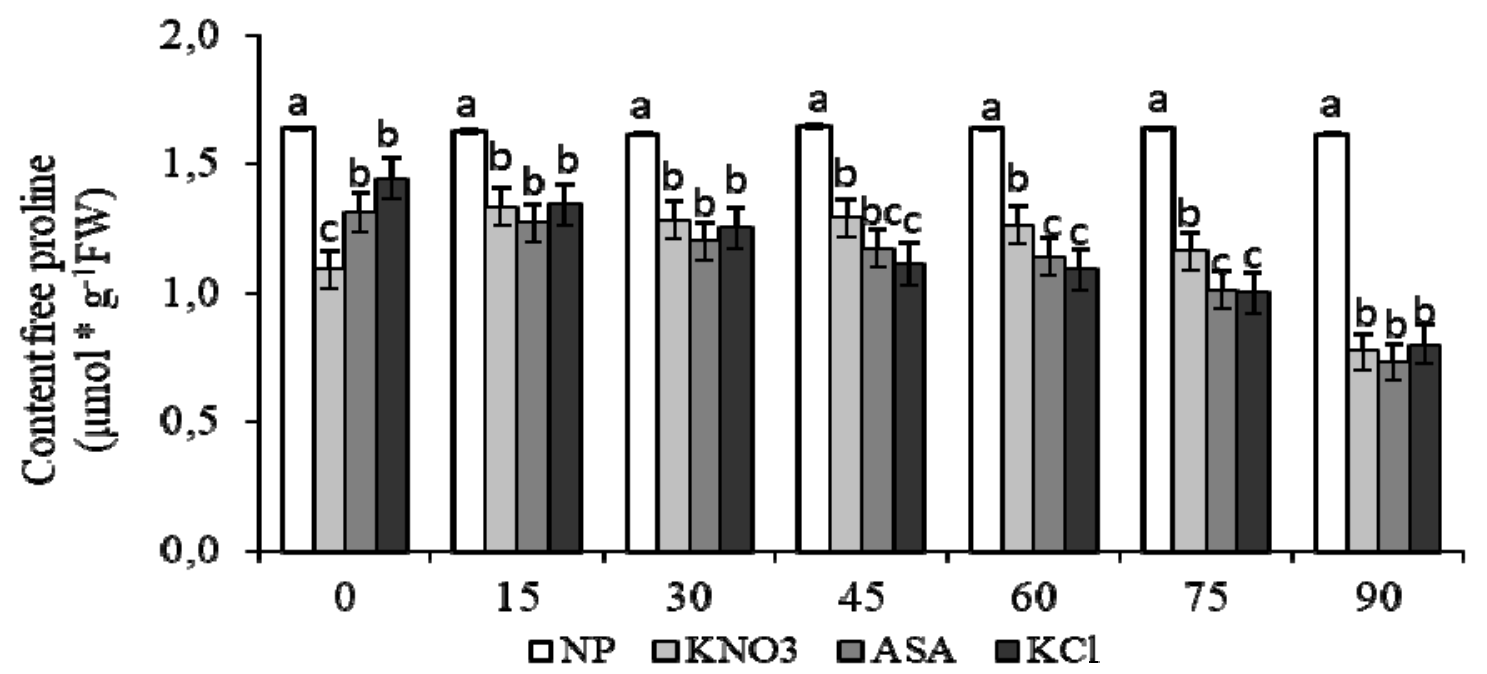

Figure 4. Effect of priming on free proline content (mmol/gFW) during seed storage (Values marked by the same letter are not significantly different at $P=0.01$ level of probability - Tukey's Multiple Range Test)

The results are consistent with the research conducted by Demiral and Turkan (2006). They emphasized that free proline, when found in optimal concentrations, acts as an osmoprotectant, located in the cytoplasm, as a stabilizer of enzymes, of the macromolecule and organelle structure, and as a remover of reactive oxygen species (ROS). However, at lower concentrations, its positive effect on enzymes necessary for embryo nutrition, and thus for seed germination and obtaining typical seedlings, decreases (Iqbal et al., 2002).

The content of vitamin $\mathrm{C}$ did not change significantly in non-primed seeds during 90 days of storage. In primed seeds, vitamin C content varied depending on the solution and storage time. Immediately after priming the seeds in a solution of $\mathrm{KNO}_{3}$ and $\mathrm{KCl}$, the concentration of vitamin $\mathrm{C}$ was significantly reduced. In the period from 15 to 30 days, 
there was a significant increase in vitamin C content, regardless of the solution applied. Thereafter, with the action of $\mathrm{KNO}_{3}$, the level of vitamin $\mathrm{C}$ was significantly reduced in soybean seedlings. Ninety days after priming, the proportion of vitamin $\mathrm{C}$ was about four times lower than in non-primed seeds. AsA and $\mathrm{KCl}$ solutions increased the content of vitamin $\mathrm{C}$ in soybean seedlings from 15 to 45 days. Thereafter, the concentration of vitamin $\mathrm{C}$ was significantly reduced by the application of $\mathrm{KCl}$, while the use of AsA reduced the content of vitamin $\mathrm{C}$ after 60 days (Figure 5).

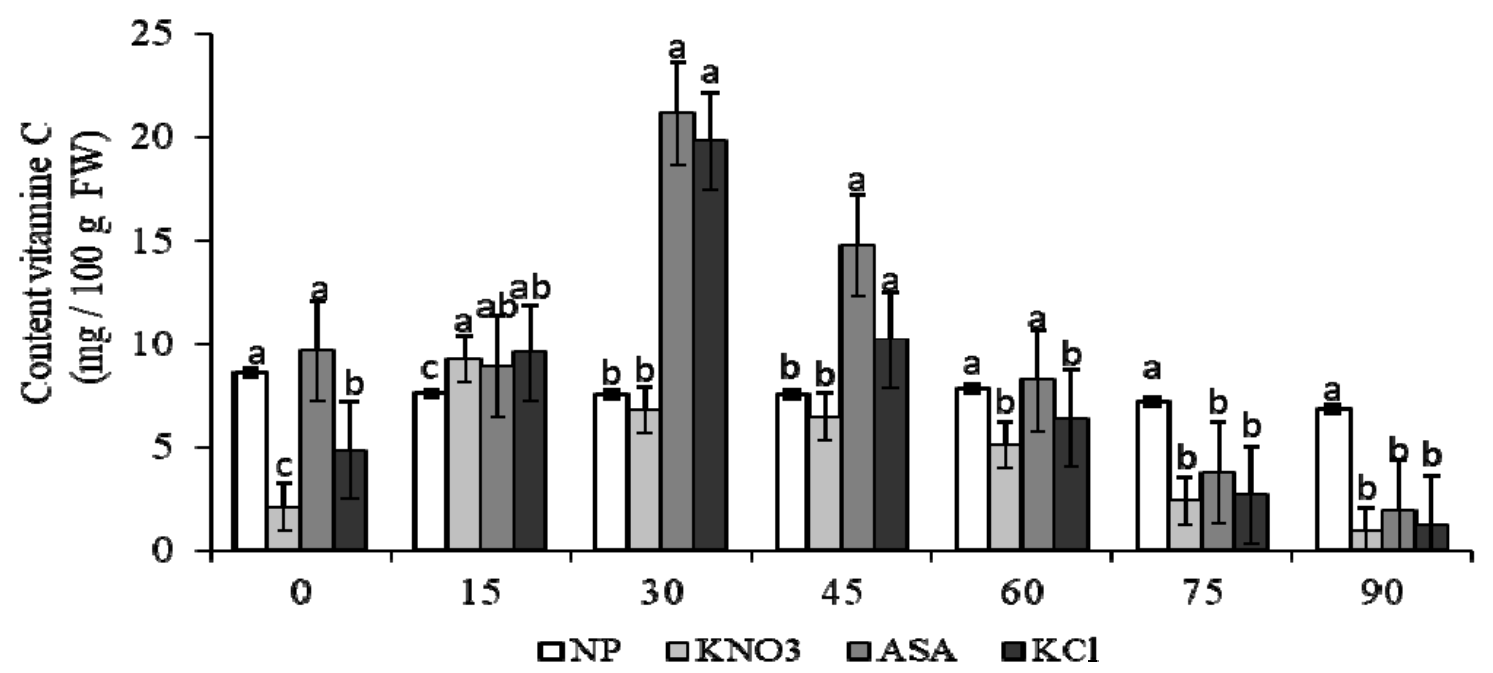

Figure 5. Effect of priming on vitamin $\mathrm{C}$ content (mg/100gFW) during seed storage (Values marked by the same letter are not significantly different at $P=0.01$ level of probability - Tukey's Multiple Range Test)

Vitamin C mainly acts as an antioxidant under stressful conditions and thus reduces the negative impact of environmental factors. Under stressful conditions, there is a higher concentration of reactive oxygen species such as the hydroxyl radical formed from hydrogen peroxide. Reactive oxygen species are harmful to plants because they can react with nucleic acids, proteins and lipids. In some cases, they initiate chain reactions, which can be interrupted by ascorbic acid, which thus reduces the negative impact of environmental factors (Verelst et al., 2010). Also, ascorbic acid can protect metabolic processes from toxic oxygen derivatives that affect various enzymatic activities and thus reduce the damage caused by oxidative processes (Pourcel et al., 2007).

\section{Conclusions}

The analysis showed that, for seeds stored in paper bags, the reduction in the quality of primed seeds was considerably faster than in non-primed seeds in natron paper bags. Primed soybean seeds were successfully stored at a temperature of $25^{\circ} \mathrm{C}$ during 60 days after priming, and after that period, there was a significant reduction in their quality. Seventy-five days after priming, germination energy was reduced by $60.33 \%$ and germination by $9.33 \%$, while after 90 days the reduction was $68.33 \%$ and $65 \%$, respectively. Seed quality reduction was caused, inter alia, by an increase in MDA content, especially after 90 days of storage. After 90 days, the content of MDA increased, on average, by $38.41 \%$ in relation to non-primed seeds. Also, free proline concentration was reduced while the content of vitamin $C$ increased after 15 days, primarily in seeds immersed in AsA and $\mathrm{KCl}$ solutions, and decreased after 45 days.

\section{Acknowledgment}

This research was supported by the Ministry of Education, Science and Technological Development of the Republic of Serbia, grant number: 451-03-9/2021$14 / 200032$.

\section{References}

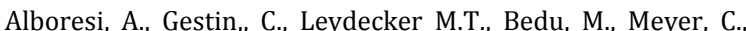
Truong, H.N. (2005). Nitrate, a signal relieving seed dormancy in Arabidopsis. Plant, Cell \& Environment, 28(4), 500-512.

Argerich, A., Bradford, K. J. (1989). The effects of priming and ageing on seed vigour in tomato. Journal of Experimental Botany, 40, 599-607.

Arun, M. N., Shankara, Hebbar, S., Bhanuprakas, K., Senthivel, T. (2017). Seed priming improves irrigation water use efficiency, yield and yield components of summer cowpea under limited water conditions. Legume Research-An International Journal, 40(5), 864-871.

Bates, L.S., Waklren, R.P. Teare, I.D. (1973). Rapid determination of free proline for water stress studies. Plant and Soil, 39, 205-207.

Benderitter, M., Maupoli, V., Vergely, C., Dalloz, F., Briot, F., Rochette, L. (1998). Studies by electron paramagnetic resonance of the importance of iron in the hydroxyl scavenging properties of ascorbic acid in plasma: Effects of iron chelators. Fundamental of Clinical Pharmacology, 12, 510-516.

Chang, S. M., Sung, J. M. (1998). Deteriorative changes in primed sweet corn seeds during storage. Seed Science Technology, 26, 613-626.

Cvijanović, G., Čolić, N., Đurić, N., Dozet, G., Eltreki, A., Cvijanović, M., Žuža, M. (2020). Effect of biostimulants on soybean seedlings. Acta Agriculturae Serbica, 25(50), 99104.

Demiral, T., Turkan, I. (2006). Exogenous glycinebetaine affects growth and proline accumulation and retards senescence in two rice cultivars under $\mathrm{NaCl}$ stress. Environmental and Experimental Botany, 56, 72-79. 
Dolatabadian, A., Sanavy, S. A. M. M., Chashmi, N.A. (2008). The effects of foliar application of ascorbic acid (vitamin C) on antioxidant enzymes activities, lipid peroxidation and proline accumulation of canola (Brassica napus L.) under conditions of salt stress. Journal of Agronomy and Crop Science, 194, 206-213.

Drew, R. L. K., Hands, L. J., Gray, D. (1997). Relating the effects of priming to germination of unprimed seeds. Seed Science and Technology, 25, 537-548.

Giri, M.D., Jaybhaye, C.P., Kanwade, D. G. (2021). Seed priming: A low-cost input for yield maximization of rainfed chickpea. Legume Research - An International Journal, DOI:10.18805/LR-4507.

Iqbal, N., Basra, S. M. A., Ur-Rehman, K. (2002). Evaluation of vigour and oil quality in cotton seed during accelerated ageing. International Journal of Agriculture \& Biology, 4, 318-322.

Meena, K. K., Sorty, A. M., Bitla, U. M., Choudhary, K., Gupta, P., Pareek, A., Singh, D. P., Prabha, R., Sahu, P. K., Gupta, V. K., Singh, H. B., Krishanani, K. K., Minhas, P. S. (2017). Abiotic stress responses and microbe-mediated mitigation in plants: The omics strategies. Frontiers in Plant Science, 8,172 .

Miladinov, Z., Baleševic-Tubić, S., Đordjević, V., Đukić, V., Ilić, A Čobanović, L. (2015). Optimal time of soybean seed priming and primer effect under salt stress conditions. Journal of Agricultural Sciences, 60, 109-117.

Miladinov, Z., Balešević-Tubić, S., Đukić, V., Ilic, A., Čobanović, L., Dozet, G., Merkulov-Popadić, L. (2018). Effect of priming on soybean seed germination parameters. Acta Agriculturae Serbica, 23(45), 15-26.

Miladinov, Z., Maksimović, I., Balešević-Tubić, S., Đukić, V.,, Nikolić, Z., Milošević, B., Katanski, S. (2020). Priming seeds - method for increasing the germination of soybean seeds under drought stress conditions. Acta Agriculturae Serbica, 25(50), 105-111.

Milošević, M., Ćirović, M., Mihaljev, I., Dokić, P. (1996). Opšte semenarstvo. Novi Sad: Institut za ratarstvo i povrtarstvo, 53-60.

Mirić, M., Brkić, M. (2002). Dorada semena. Društvo selekcionera i semenara Republike Srbije, Beograd.

Nirmala, K., Umarani, R. (2014). Storage potential of primed seeds of okra (Abelmoschus esculentus) and beet root (Beta vulgaris). Australian Journal of Crop Science, 8(9), 1290-1297.
Owen, P.L., Pill, W.G. (1994). Germination of osmotically primed asparagus and tomato seeds after storage up to three months. Journal of the American Society for Horticultural Science, 119(3), 636-641.

Placer, Z.A., Cushman, L.L., Johnson, B.C. (1966). Estimation of product of lipid peroxidation (malonyl dialdehyde) in biochemical systems. Analytical Biochemistry,16, 359364.

Poštic, D., Protić, R., Aleksić, G., Gavrilović, V., Živković, S., Trkulja, N., Ivanović, Z. (2010). Ispitivanje kvaliteta semena ozime pšenice u periodu 2000-2005. godine. Zaštita bilja, 61, 20-24.

Pourcel, L., Routaboul, J. M., Cheynier, V., Lepiniec, L., Debeaujon, I. (2007). Flavonoid oxidation in plants: From biochemical properties to physiological functions. Trends in Plant Science, 12, 29-36.

Pukacka, S., Ratajczak, E. (2005). Production and scavenging of reactive oxygen species in Fagus sylvatica seeds during storage at varied temperature and humidity. Journal of Plant Physiology, 162, 873-885.

Saracco, F., Bino, R. J., Bergervoet, J. H. W, Lanteri, S. (1995). Influence of priming-induced nuclear replication activity on storability of pepper (Capsicum annuum L.) seed. Seed Science Research, 5, 25-29.

Sivasubramaniam, K., Geetha, R., Sujatha, K., Raja, K., Sripunitha, A., Selvarani, R. (2011). Seed priming: triumphs and tribulations. The Madras Agricultural Journal, 98, 197-209.

Van Pijlen, J.G., Groot, S. P. C., Kraak, H. L., Bino, R. J. (1996). Effect of pre-storage hydration treatments on germination performance, moisture content, DNA synthesis and controlled deterioration tolerance of tomato (Lycopersicon esculentum Mill) seeds. Seed Science Research, 6, 57-63.

Verelst, W., Skirycz, A., Inzé, D. (2010). Abscisic acid, ethylene and gibberellic acid act at different developmental stages to instruct the adaptation of young leaves to stress. Plant Signaling \& Behavior, 5, 473-475.

Vijayakumar, G., Manghat, S., Vijayakumar, R., Simon, L., Scaria, L. M., Vijayakumar, A., Sreehari, G. K., Kutty, V. R., Rachana, A., Jaleel, A. (2019). Incidence of type 2 diabetes mellitus and prediabetes in Kerala, India: results from a 10-year prospective cohort. BMC Public Health, 19, 140. 